\title{
The Effect of The Entrepreneurial Career Intention Program (ECIP) on The Entrepreneurial Career Intention (ECI) among Counseling Students in A Private Institution of Higher Learning in Malaysia
}

Norasyikin Mohaiyuddin, Nordin Kardi, Mohammad Aziz Shah Mohamed Arip

To Link this Article: http://dx.doi.org/10.6007/IJARBSS/v11-i10/11496 DOI:10.6007/IJARBSS/v11-i10/11496

Received: 16 August 2021, Revised: 18 September 2021, Accepted: 06 October 2021

Published Online: 20 October 2021

In-Text Citation: (Mohaiyuddin et al., 2021)

To Cite this Article: Mohaiyuddin, N., Kardi, N., \& Arip, M. A. S. M. (2021). The Effect of The Entrepreneurial Career Intention Program (ECIP) on The Entrepreneurial Career Intention (ECI) among Counseling Students in A Private Institution of Higher Learning in Malaysia. International Journal of Academic Research in Business and Social Sciences, 11(10), $1200-1205$.

Copyright: (C) 2021 The Author(s)

Published by Human Resource Management Academic Research Society (www.hrmars.com) This article is published under the Creative Commons Attribution (CC BY 4.0) license. Anyone may reproduce, distribute, translate and create derivative works of this article (for both commercial and non-commercial purposes), subject to full attribution to the original publication and authors. The full terms of this license may be seen at: http://creativecommons.org/licences/by/4.0/legalcode

Vol. 11, No. 10, 2021, Pg. $1200-1205$

Full Terms \& Conditions of access and use can be found at http://hrmars.com/index.php/pages/detail/publication-ethics 


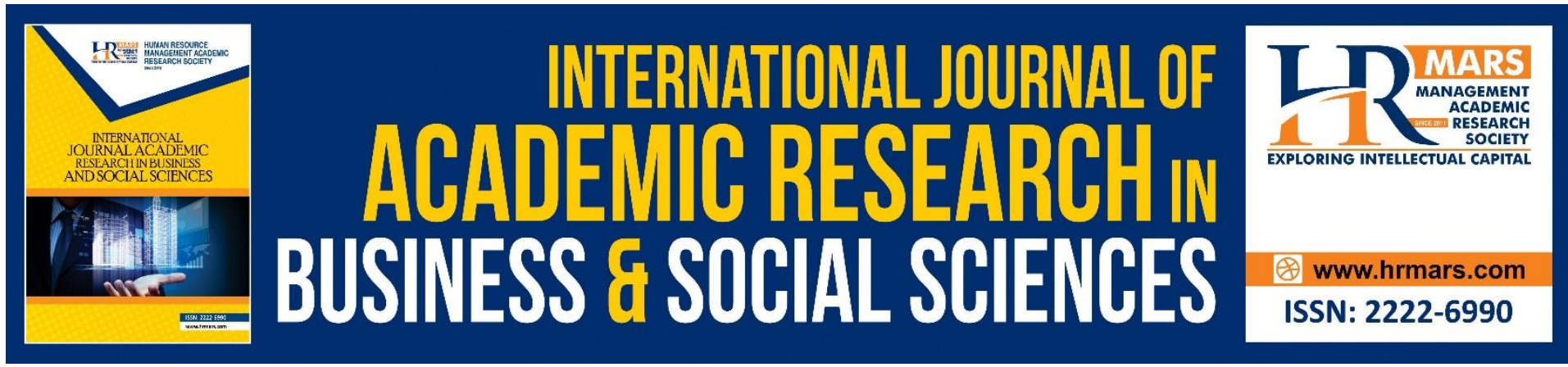

\title{
The Effect of The Entrepreneurial Career Intention Program (ECIP) on The Entrepreneurial Career Intention (ECI) among Counseling Students in A Private Institution of Higher Learning in Malaysia
}

\author{
Norasyikin Mohaiyuddin, Nordin Kardi, Mohammad Aziz Shah \\ Mohamed Arip \\ Sultan Azlan Shah University, Malaysia
}

\begin{abstract}
Entrepreneurship education programs were found to increase the country's economic growth and reduce the graduate unemployment rate. The more important need for entrepreneurship education is how to cultivate the intention or interest of students to engage in the entrepreneurial career. Entrepreneurship education needs to be more structured and effective to foster an entrepreneurial culture among students. The main objective of this study was to evaluate the impact of the Entrepreneurial Career Intention Program (ECIP) in one of private higher learnings in Malaysia. This program uses a module develop from the integration Cognitive Behavioral Therapy (CBT) and Theory of Planned Behavior (TPB). The results showed that the program showed differences in intention scores according to time and also differences by the group. This study shows that the approach in CBT can increase Entrepreneurial Career Intention (ECI) using the structure in TPB. Finally, the findings of this study suggest a psychological counseling approach can be used in entrepreneurship programs to improve intention scores.
\end{abstract}

Keywords: Career, Intention, Entrepreneurship and Counselling

\section{Introduction}

Entrepreneurship education programs in institutions of higher learning in Malaysia are more focused on learning programs across the academic curriculum. However, the rate of student involvement in entrepreneurial careers is still low. This shows that careers in the entrepreneurship is not a student's first choice and the number of those who venture into the field of entrepreneurship is still small (Norasmah \& Salmah, 2011). The current need is to implement more appropriate programs to develop intention among students (Ng et al., 2016). Entrepreneurship programs can be an appropriate method to cultivate entrepreneurial intention and universities should play a role in motivating students by providing appropriate training to instill a positive attitude of students towards entrepreneurship. Initiatives 1 and 2 outlined in the Entrepreneurship Action Plan 2016-2020 target 100\% of students in higher learning institutions to gain exposure to entrepreneurial culture and attribution as well as $5 \%$ 
of graduate students to make entrepreneurship a career. To achieve this target, the two initiatives are proposed to implement high-impact educational practices by applying entrepreneurial elements across the curriculum and fields of study as well as implementing a job creator framework.

However, to date, the rate of student involvement in entrepreneurial activities in public and private institutions of higher learning is still low. This statement can be seen clearly based on the current statistics of student involvement in entrepreneurship after a various entrepreneurship programs are conducted to all institutions of higher learning. To date, only $2.5 \%$ or 3,755 graduates are involved in entrepreneurship after graduation while the number of unemployed graduates reaches tens of thousands every year.

In conclusion, the need for specific studies on the development and effectiveness of entrepreneurial career intention programs of students in university need to learn more to which the program can affect the intention.

\section{Objectives of the Study}

The objective of this study is to evaluate the effect of the Entrepreneurial Career Intention Program (ECIP) on the entrepreneurial career intention (ECI) of students in one private university in Malaysia.

\section{Literature Review}

This study was conducted with reference to various previous studies in relation to entrepreneurial determination.

A similar study was conducted by Chung et al (2018) that improvement and re-evaluation of entrepreneurship programs and courses need to be carried out. Most entrepreneurship programs tend to focus on finance and business ownership such as how to make business plans or prepare proposals to potential investor candidates, while many studies show the success of a business starts with the entrepreneurial mindset and attitude of the individual himself (Chung et al., 2018).

The study of Amanuddin et al (2018), tested four factors that influence entrepreneurial career intention, namely entrepreneurship education, age, personality attribution and influence of family members. The result of the study is that the more students gain knowledge about entrepreneurship the less their tendency to engage in entrepreneurship. Students tend to give priority to academics and entering this field has great challenges.

Lu and Wang (2018) in a study testing entrepreneurial sensitivity is expected to play a role in the model of planned behavior. The results found that the three dimensions of sensitivity individually mediate the influence of entrepreneurial attitudes on entrepreneurial intention, the influence of subjective norms on entrepreneurial intention, and the influence of behavioral control on entrepreneurship. This study explains that by influencing the sensitivity or awareness of entrepreneurship it will also affect the entrepreneurial career intention.

The study of Badariah et al (2016) suggested that public and private institutions of higher learning in the country should encourage students with the basics of entrepreneurship. Entrepreneurship programs also need to make improvements to the learning outcomes of the course to ensure that students can learn more deeply about the importance of entrepreneurial skills that benefit their future. The results of this study also suggest several 
things as improvements based on the findings of the analysis that have been obtained. The regression analysis showed that the variables of business planning, risk thinking, need for achievement, and locus of control showed a significant relationship with the effectiveness of the entrepreneurship program. While self-efficacy did not show a significant relationship on the effectiveness of entrepreneurship programs.

Hypothesis 1:

There were no significant differences in the mean measures of pre-test as well as post-test for the variables of entrepreneurial career intention $(\mathrm{ECl})$ between the treatment groups compared to the control group.

1.1 There was no significant difference in the mean measures of pre-test and post-test variables dependent on entrepreneurial career intention $(\mathrm{ECl})$ between the treatments groups compared to the control group based to time.

1.2 There was no significant difference in the mean measures of pre-test and post -test of $\mathrm{ECl}$ dependent variables between treatment groups compared to control groups based to group.

1.3 There was no significant difference in the mean measures of pre -test and post -test of $\mathrm{ECl}$ dependent variables between treatment groups compared to control groups based to time and group integration.

\section{Method}

This study is an experimental study involving 100 students of the Bachelor of Counseling of Sultan Azlan Shah University. The pre-test was given a week before the study subjects attended the test while the post-test was given a week after the study completed the treatment session. A SPANOVA analysis was conducted to look at the impact of the program on students' ECI.

\section{Findings}

Table 1: $\quad$ Summary of SPANOVA analysis on treatment group and control group for Entrepreneurial Career Intention (ECl).

\begin{tabular}{llllll}
\hline Variable & Source & SQ & DF & F & Sig. \\
\hline Entrepreneurial & Time & .716 & 1 & 5.101 & .026 \\
$\begin{array}{l}\text { Career Intention } \\
\text { (ECI) }\end{array}$ & Group & 4.055 & 1 & 11.823 & .001 \\
& Time* Group & .203 & 1 & 1.443 & .232 \\
\hline
\end{tabular}

$p>.05$

The results of the SPANOVA test conducted on the $\mathrm{ECl}$ variables of the treatment group and the control group are shown in Table 1 . The results showed that there was a time effect on the intention variable that was $F(1,98)=5.101$, sig $=.026(p<.05)$. This finding means that the $\mathrm{ECl}$ variable changes significantly over time so hypothesis 1.1 is rejected. For the group effect, there was no significant effect of $E C l$ variable, i.e. $F(1,98)=4.055$, sig $=.001(p<.05)$. These findings indicate that the treatment group was more effective than the control group. The group effect showed a significant effect on the $\mathrm{ECl}$ variable. These results also showed 
that treatment factors influenced the change of ECI. Thus hypothesis 1.2 was rejected and there was a significant difference in the mean of pre -test and post -test $\mathrm{ECl}$ scores by group. However, on the overall, the table above also shows that there is an insignificant effect of group time*interaction on the intention, $F(1,98)=1.443$, sig. $232(p>.05)$. This finding means that there is no effect of interaction between time and group on the $\mathrm{ECl}$ score. Thus, the researcher concluded that the treatment given had an effect on time to the study subjects but the effect of interaction between groups showed the opposite effect that had no effect on students' ECl. Then hypothesis 1.3 is failed to reject.

\section{Conclusion}

In conclusion, there is a significant difference between the mean of pre-test and post -test for the $\mathrm{ECl}$ students. The results of the study clearly show that there are significant differences of dependent variables post-test. However, from a practical point of view, if viewed from the point of view of time interacting with the group, it was found to show no significant difference. The findings of this study show that the $\mathrm{ECl}$ program affects the increase in mean intention either for the treatment group or the control group. The insignificant findings of the treatment group and the control group in which both of these groups showed an increase in mean values when post-testing were performed. Researcher refers to the study of Emanuel, et al (2012) which looked at the impact of entrepreneurship education programs on study subjects from the field of business while career guidance to study subjects in the field of guidance and counseling. The results of the study showed that the study subjects in the field of guidance and counseling were found to have higher ECI than the study subjects in the field of business. This is due to the exposure to career guidance and support received by the counseling guidance study subjects compared to the entrepreneurship courses followed by the business students. This indicates that the exposure to career guidance received by the research subjects from the field of counseling guidance either from the treatment group or the control group influenced the entrepreneurial intention of the study subjects. The conclusion is that the exposure to career guidance received by the students' subjects in the study also affects the entrepreneurial intention.

\section{Corresponding Author}

Nordin Kardi

Sultan Azlan Shah University, Malaysia

\section{References}

Chung, G. B., Chang, S. S., \& Joo, Y. P., \& Dae, S. C. (2018). A study on the effective of effectiveness of entrepreneurship educations programs in higher education institutions: A Case Study of Korean Graduate Programs. Journal of Open Innovation, 4.26, 1-14.

Creswell, J. W. (2014). Research Design: Qualitative, Quantitative, and Mixed Methods Approaches: SAGE Publication. Thousand Oaks, California.

Din, B., Anuar, A., \& Usman, M. (2016). The effectiveness of the entrepreneurship education program in upgrading entrepreneurial skill among public university students. Procedia Social and Behavioural Scienses, 224 (2016) 117-123.

Emanuel, S., Adejoke, B. K., OLugbenga, Victor, O., \& Olatunde, O. L. (2012). Entrepreneurial Intention among business and counseling students in Lagos State University. Journal of Education and Practice, 3:14.

Fraenkel, J. R., \& Norman, E. W. (2012). How To Design and Evaluate Research in Education. 
8th Edition. New York. McGraw-Hill.

Lu, H., \& Wang, J. (2018). Entrepreneurial Intention of Two Patterns of Planned Behavior and Alertness: Empirical Evidence in China. Journal of Asian Finance, Economic and Business, $5(2), 63-72$.

Ministry of High Education. (2016). The Entrepreneurship Action Plan 2020. http://mohe.gov.my

Nguyen, C. (2017). Entrepreneurial intention of international business students in Vietnam: A survey of the country joining the trans-pacific partnership. Journal of Innovation and Entrepreneurship, 6 (7), 1-13.

Othman, N., \& Ishak, S. (2011). Tendency towards entrepreneurial career choice according to the perceptions of student entrepreneur scheme participants. Journal of Technology, 56 (Social Science), 47-63.

Robledo, J. L. R., Aran, M. V., Martin-Sanchez, V., \& Molina, M. A. R. (2015). The moderating role of gender on entrepreneurial intentions. A TPB Perspective Intangible Capital, 11 (1), 92-117.

Shamsuddin, A., Kumaran, T., Rosli, N. S., Kurup, V., \& Zawari, M. Z. (2018). Factors influence graduates in becoming entrepreneurs among accounting students in Malaysia University. International Journal of Business, Economics and Laws, 15(4).87-98. 